\title{
LAS REPRESENTACIONES INDÍGENAS Y LA PUGNA POR LAS IMÁGENES. MÉXICO Y BOLIVIA A TRAVÉS DEL CINE Y EL VIDEO
}

\author{
Ana Daniela Nahmad Rodríguez*
}

...uno no es más que una cierta mirada sobre el mundo. ${ }^{1}$

\begin{abstract}
RESUMEN: En este texto se analizan las construcciones visuales formuladas sobre los grupos originarios latinoamericanos, enfatizando la existencia actual de una lucha por las representaciones, ya que en ellas se sintetizan ejercicios de poder y dominación. Este fenómeno se contrasta con la resistencia que los grupos indígenas han emprendido ante la colonialidad de las imágenes, mediante el manejo de los medios de comunicación audiovisual. Se tejen las relaciones entre política, cultura e imagen para demostrar el conflicto de los indígenas latinoamericanos frente a las hegemonías culturales y económicas.
\end{abstract}

Palabras Clave: Cine sobre indígenas, Representaciones visuales, Nacionalismo, Medios de comunicación, Movimiento indígena, México, Bolivia.

ABSTRACT: In this text are analyzed the visual constructions formulated on the groups of Latin American natives, emphasizing the current existence of a fight for the representations, since in them exercises of power and dominance are synthesized. This phenomenon is contrasted with the resistance that the indigenous groups have undertaken before the "colonization" of the images, by means of the handling of the audiovisual media. The relationships are knitted among politics, culture and image to demonstrate the conflict of the Latin American natives in front of the cultural and economic hegemonies.

KEY WORDS: Native movies, Visual representations, Nationalism, Media communication, Indigenous movements, Mexico, Bolivia.

En la red electrónica de noticias indígenas Ukhamawa apareció, en diciembre del año pasado, una crítica a la cinta Apocalypto (2006) de Mel

\footnotetext{
*Facultad de Filosofía y Letras, unAm (aninahmad@yahoo.com.mx.).

${ }^{1}$ Adolfo Colombres, "Prólogo a la segunda edición", en Adolfo Colombres [ed.], Cine, antropología y colonialismo, 2a ed., Buenos Aires, Del Sol, 2005, p. 13.
} 
Gibson; la invectiva fue realizada por un grupo indígena maya y la nota decía lo siguiente:

Si La pasión de Cristo había despertado resquemor en la comunidad judía, el nuevo largometraje como director [sic] de Mel Gibson, Apocalypto, está causando similar reacción en un grupo de indígenas guatemaltecos, que han señalado que la película sobre el declive de la civilización Maya [sic] los muestra como salvajes.

Gibson enseña, en glorioso technicolor de gran presupuesto, una ofensiva y racista noción de que los Mayas eran brutales entre sí, mucho antes de la llegada de los europeos, y que ellos se merecían, de hecho, necesitaban, "ser rescatados", dijo Ignacio Ochoa, director de la Fundación Nahual que promueve la Cultura Maya [sic], a Reuters. Este activista guatemalteco, si bien no tuvo acceso al film, aseguró que las imágenes promocionales del largometraje y los trailers proyectados en las salas de cine permiten ver la visión de Gibson, plagada de estereotipos sobre esta cultura, donde se incluyen sangrientos sacrificios. ${ }^{2}$

Esta enérgica protesta contra los estereotipos visuales sobre los indios mayas, generados desde la hegemonía cinematográfica localizada en Hollywood, muestra cuan actual es el debate por las imágenes de los indígenas en los medios de comunicación. Las comunidades originarias de América Latina y del mundo enfrentan una encarnizada lucha por implantar representaciones más fidedignas sobre ellos, su cultura y su pasado. En este artículo se realizará un breve recorrido por las producciones cinematográficas sobre los indígenas, enfatizando su relación con las construcciones nacionalistas y la dominación hacia ellos. En primera instancia se analizará el caso de México, por haber constituido una hegemonía visual para América Latina en la primera mitad del siglo XX, para después contrastarlo con el caso boliviano, donde a partir de la década de los sesenta se comienza a gestar una resistencia frente a la construcción de esas imágenes encubridoras. Finalmente se considerarán las implicaciones del video indígena para América Latina.

${ }^{2}$ Ukhamawa, sábado 9 de diciembre, 2006. En http://espanol.groups.yahoo.com/group/ukhamawa/. 
En esta sociedad hipervisual encontramos una guerra constante por las imágenes. Desde la invención/conquista de América la imagen y representación de los indígenas significó una querella por la identidad, no únicamente la de ellos, sino también por las otras identidades a las que se enfrentaron (las de los colonizadores). En este nuevo siglo se agudiza el conflicto, ya que la generación de representaciones sintetiza las disputas por el ejercicio del poder. Por ello es necesario interpretar tanto las imágenes generadas por los indígenas, como las construidas sobre ellos, como formas de creación de significados estrechamente relacionados a proyectos políticos y culturales de producción de identidades que, en la mayoría de los casos, entran en controversia.

La iconografía sobre los grupos originarios ha sido un correlato de la dominación que los estados, las hegemonías culturales y económicas han ejercido en otros ámbitos de la vida social, sirviendo para justificar las políticas de integración, pauperización y homogeneización sobre los pueblos y sobre la diversidad de sus identidades. El cine y, posteriormente, el video han tomado parte en los espacios de lucha por las representaciones, las imágenes en movimiento han tenido una participación determinante en la construcción de identidades y subjetividades sociales ${ }^{3}$ $\mathrm{y}$, como poseedoras de formas de producir sentidos, han estado vinculadas a la construcción de ideologías y a las luchas por la hegemonía.

Hace algunos años Armando Bartra visualizaba de esta forma el problema: "En el fin del milenio hay una disputa por la imagen del indio. No sólo por la representación —en literatura, pintura, fotografía, cine o video - sino por el concepto. Detrás del debate sobre los derechos étnicos lo que está en cuestión es la idea misma de la indianidad". Esto nos

${ }^{3}$ Cristian León, "Racismo, políticas de la identidad y construcción de 'otredades' en el cine ecuatoriano", Revista Chilena de antropología visual, Universidad Academia de Humanismo Cristiano.

En http://www.antropologiavisual.cl/leon imprimir.htm., p. 1.

${ }^{4}$ Armando Bartra, "Imágenes encontradas", La Jornada, Sección Hojarasca, año 9, núm. 23, México, marzo, 1999. 
remite a una dimensión de la vida social de suma importancia para el estudio de las relaciones interétnicas en América Latina: la cuestión de la identidad y la representación.

Los procesos de etnización van de la mano con las delimitaciones identitarias que realizan los distintos grupos. Siguiendo a Gilberto Giménez Montiel, la etnicidad es un elemento que organiza socialmente la diferencia y es producto de procesos históricos de identificación. Las identidades colectivas son construcciones sociohistóricas determinadas que se definen de manera exógena y endógena a la vez, y por ello son objeto de disputa en las luchas sociales por la "clasificación legítima": ya que no todos los grupos tienen las mismas posibilidades de identificación, sólo los que ejercen el poder pueden imponer la definición de sí mismos y la de los demás. ${ }^{5}$

A través del desarrollo histórico de la modernidad, las élites y el Estado han ejercido lo que Gilberto Giménez llama "políticas de identificación", reservándose la administración de la identidad, imponiendo una mono-identificación, una sola identidad cultural legítima, que ha funcionado como el sustento imaginario de los estados nacionales. ${ }^{6}$ En el repertorio cultural nacionalista la imagen del indio ha sido parte esencial de la construcción de las identidades en los países latinoamericanos, ya fuera para negarla y afirmarse sobre su exterminio o para exaltarla y afianzarse sobre su glorioso pasado. Desde las prefiguraciones del nacionalismo, el pasado indígena fue apropiado por parte de los criollos que imaginaban su nueva comunidad. Esta apropiación fue una tradición que se agudizaría a partir del siglo XIX, que traspasaría los umbrales del siglo XX y las coyunturas revolucionarias.

Otro elemento importante en este proceso es la construcción de la idea de nación y los proyectos políticos que la acompañan. El naciona-

${ }^{5}$ Gilberto Giménez, "Identidades étnicas: estado de la cuestión”, en Leticia Reina [coord.], Los retos de la etnicidad en los estados-nación del siglo XXI, México, CIESAS, INI, Porrúa, 2000, pp. 45-70, pp. 13-14.

${ }^{6}$ Ibid., p. 14. 
lismo es un artefacto cultural construido por una determinada comunidad; es el producto de la imaginación política de cierto sector o grupo social, que mediante la masificación de las representaciones logra imponer y hacer que otros sectores sociales interioricen su propuesta. El nacionalismo es histórico y de acuerdo con la época y la región toma matices propios; sin embargo, posee características que permiten su utilización como concepto. Algunas de ellas, siguiendo a Benedict Anderson, son: la noción que tiene de su soberanía, así como de sus límites (que representan las otras naciones) y de su propia imagen de comunidad horizontal, a pesar de las contradicciones sociales a su interior. Es una ideología, entendida como las conceptuaciones de un grupo específico que se buscan imponer a sectores más amplios. Finalmente, es una práctica social retomada por los sectores populares, que al tiempo de asumirlo lo reconstruyen.

En América Latina el nacionalismo ha implicado una identificación y valoración de lo propio negando y diferenciándose de lo extraño o extranjero, esta negación conformó las identidades de las élites que se afirmaron frente a los elementos considerados ajenos y subalternos, como los indígenas, los negros o los extranjeros, construyéndose gracias a esa diferencia. Según Eric Hobsbawm "los nuevos medios de comunicación permitieron estandarizar, homogeneizar y transformar las ideologías populares", ocasionando que los símbolos nacionales pasaran a formar parte de la vida de todos los individuos. ${ }^{7}$ Durante el siglo xx la ideología nacionalista salió de sus habituales trincheras y transformó sus argumentos para encontrar nuevos canales de expresión, principalmente en las nuevas tecnologías. ${ }^{8}$ El cine se convirtió en una expresión radical de lo que siglos atrás había comenzado con la imprenta; la noción de simultaneidad pudo propiciar la sensación de comunidad entre una multitud

${ }^{7}$ Eric Hobsbawm, Naciones y nacionalismo desde 1780, trad. de Jordi Beltrán, Barcelona, Crítica, 2000, p. 151.

${ }^{8}$ Loc. cit. 
que nunca llegaría a conocerse. ${ }^{9}$ Desde entonces las élites nacionalistas han utilizado las tecnologías de la industria cultural para legitimar su ideología, entre las que se encuentra el cine, que reformuló con su manera particular de expresión los preceptos sobre la nacionalidad.

El nacionalismo en Latinoamérica tomó un lugar hegemónico en la producción de discursos cuando se extinguió el colonialismo como sistema político formal; sin embargo, la colonialidad del poder se ha mantenido sobre la base de los criterios originados en las relaciones de desigualdad y "no ha dejado de ser el carácter central del poder actual". ${ }^{10}$ Las representaciones culturales construidas dentro de este contexto se recubren de una opresión bífida, la occidental y la propiamente latinoamericana. Recordemos que categorías como "indio", "negro", "mestizo" o "blanco" representan la "marca del nacimiento de América y la base misma del actual poder global". ${ }^{11}$ El colonialismo y, posteriormente, los indigenismos inscribieron a "lo indígena" dentro de ciertas categorías erigiéndole una pretendida identidad unívoca y normaron las relaciones que se establecieron con los grupos originarios, traduciéndose, entre otras cosas, en imágenes tecnológicas.

Heredero del lirismo decimonónico y del imaginario nacionalista, el cine latinoamericano no ha estado exento de la disputa sobre la construcción de la pretendida identidad nacional afirmándose en una visión imaginaria de los indios. En la primera mitad del siglo xx latinoamericano, por medio de la cinematografía y otros medios de reproducción técnica de las imágenes, se construyeron visualidades hegemónicas, ${ }^{12} \mathrm{es}$ decir, mecanismos de administración de imágenes y condiciones específicas de visibilidad de las diferencias culturales y étnicas, sustentando

\footnotetext{
${ }^{9}$ Cfr. Benedict Anderson, Comunidades imaginadas. Reflexiones sobre el origen y difusión del nacionalismo, México, FCE, 2005.

${ }^{10}$ Aníbal Quijano, “'Raza', 'etnia' y 'nación' en Mariátegui. Cuestiones abiertas”, en José Carlos Mariátegui y Europa: La otra cara del descubrimiento, Lima, Amauta, 1992 , p. 1.

${ }^{11}$ Loc. cit.

${ }^{12}$ León, op. cit., p. 3.
} 
simbólicamente la pretendida y muy afanada estructuración de un paradigma unitario de nación: esa fue la gran tarea que se autoasignaron los intelectuales mestizos o criollos miembros de las élites en el poder.

En México sabemos de las emblemáticas, y también desaparecidas, imágenes de Manuel Gamio tomadas en Teotihuacan o el filme Cuauhtémoc (1904) de Carlos Mongrand. ${ }^{13}$ Manuel Cirerol y Carlos Martínez Arredondo serían otros dos promotores de la exaltación del heroísmo indígena en la pantalla con la filmación de El suplicio de Cuauhtémoc en 1910, La voz de su raza (1914 circa), así como Tiempos Mayas (19151916). ${ }^{14}$ Finalmente, Tabaré (1917) de Luís Lezama, basada en el poema homónimo del uruguayo José Zorrilla de San Martín, sería una obra clave dentro de la representación indígena en el cine mexicano de los primeros tiempos, pues compartió con las cintas del momento tema de la exaltación del pasado prehispánico mediante la utilización del héroe indígena. ${ }^{15}$

En Bolivia, aunque la producción fue un tanto marginal, la presencia de la imagen indígena en los primero años de cinematografía fue un elemento imprescindible. Tenemos el caso del primer largometraje nacional titulado Corazón Aymara (1925) de Pedro Sambarino, o la cinta La profecía del lago (1925) de José María Velasco Maidana. Más adelante se realizarían La gloria de la raza (1926), de Arturo Posnansky, quien fue uno de los precursores de la investigación del pasado precolombino en dicho país y Wara-Wara (1930), el filme más importante del cine silente en Bolivia, que también poseía una temática indigenista. Las imágenes de las cinematografías latinoamericanas, durante la época silente, for-

${ }^{13}$ Federico Dávalos Orozco, Albores del cine mexicano, México, Editorial Clío, 1996. p. 22.

${ }^{14}$ Ibid., p. 23.

${ }^{15}$ No podemos dejar de mencionar las construcciones sobre los indígenas de Serguei Eisenstein en la cinta ¡Que viva México! (1929), a pesar de haber sido realizadas por un soviético, su repercusión fue fundamental, ya que fueron muy reproducidas por el nacionalismo cinematográfico de la época de oro del cine mexicano. 
mularon una visión estática sobre la identidad de los indígenas, acuñada por las élites herederas de las sociedades coloniales. ${ }^{16}$

A partir de los años cuarenta México monopolizó la industria cinematográfica latinoamericana constituyendo una visualidad hegemónica. Durante la primera mitad del siglo xx la imaginería construida desde México se propagó por América Latina y la explicación se encuentra en la Segunda Guerra Mundial. El inicio de la guerra y el pujante espíritu propagandista de Estados Unidos influyeron de una manera importante en las temáticas y "prácticamente en toda la producción fílmica mexicana durante la época." ${ }^{17}$ Como muchas áreas de la industria, la cinematográfica creció portentosamente durante el conflicto, propiciando la creación de "una nueva demanda de las películas mexicanas no sólo en el ámbito nacional, sino en todo el hemisferio occidental". ${ }^{18}$ Adentrándonos en ese momento determinante del cine mexicano, la muy exaltada época de oro, heredera de la tradición de las primeras décadas del cine sonoro, encontramos una amplia variedad de representaciones sobre los indígenas, algunas de calidad artística, otras de deplorable hechura; sin embargo, todas constituyen, en conjunto, documentos culturales que evidencian los marcos conceptuales que tradujeron la otredad indígena a

${ }^{16}$ Para más información sobre el cine boliviano consultar los siguientes libros: Alfonso Gumucio Dagrón, Historia del cine en Bolivia, Oruro, Bolivia, Editorial Los amigos del libro, 1982, de este libro existe una edición mexicana Historia del cine boliviano, México, Filmoteca de la UNAM, 1983; Carlos de Mesa Gisbert, La aventura del cine boliviano (1952-1985), La Paz, Bolivia, Editorial Gisbert, 1985; Cinemateca Boliviana, Cronología del cine boliviano (1897-1997), Notas críticas, 61, La Paz, Bolivia, Ediciones de la cinemateca boliviana, noviembre de 1997; Festival Internacional de cine y video de Oruro, Plano detalle del cine boliviano, La Paz, Bolivia, Plural Editores, 2005.

${ }^{17}$ Francisco Peredo Castro, Cine y propaganda para Latinoamérica. México y Estados Unidos en la encrucijada de los años cuarenta, México, CCYDEL-CISAN-UNAM, 2004, p. 25.

${ }^{18}$ Seth Fein, "La diplomacia del celuloide. Hollywood y la edad de oro del cine mexicano", Historia y Grafía, núm. 4, año 2, Universidad Iberoamericana, Revista Semestral, 1995, p. 141. 
los códigos de comunicación hegemónicos, para convertir al indio en uno de los grandes personajes de la mexicanidad propuesta por el cine. ${ }^{19}$

Antes de la época de oro localizamos las primeras películas sonoras de corte indigenista, como Janitzio (1934) de Carlos Navarro y La noche de los mayas (1939) de Chano Urueta; estas cintas sentarían los precedentes de las políticas de las imágenes sobre los indígenas. No obstante, María Candelaria (1943) sería la cinta del indigenismo cinematográfico por excelencia, en la que se consolidarían las pretensiones nacionalistas en el cine, logrando gran impacto en el nivel local y amplia trascendencia internacional, como en el reconocimiento recibido en Cannes. ¿Qué significaba este éxito en una película de estilo indigenista? En cierta forma era elevar al máximo la figura del indio como parte de la identidad mexicana y como un elemento que podía universalizarse. Este triunfo hizo que la temática indigenista fuera de recurrencia en los subsiguientes argumentos cinematográficos. El indio se imaginó, convirtiéndose en una institución de lo que debían ser los indios reales: piedras, paisajes, magueyes o víctimas. En el cine mexicano las imágenes de los indígenas no tuvieron densidad histórica hasta muy entrado el siglo Xx, fueron despojados de sus características étnicas, modificados para ser comprendidos, se les representó para que los co-nacionales los asumieran y para que el extranjero los aplaudiera en sus deseos folcloristas de conocer "lo mexicano".

Al indio cinematográfico de la época de oro se le inventaron características imaginarias para homogeneizarlo: el paradigma de la representación lo encontramos, finalmente, en cintas como Río escondido (1949) o Tizoc (1956), donde el indio no tuvo más atributos que el calzón y camisa de manta, reducido completamente a lo que de él pudieran hacer los mestizos. Dentro de estos filmes no hubo representación utópica, en todo caso la única utopía era que dejaran de ser indios, que desa-

${ }^{19}$ Para más información sobre la construcción de los indígenas en el cine de la época de oro ver Ana Daniela Nahmad Rodríguez, El indio imaginario: representaciones indigenas en el cine y la cultura en México. De Eisenstein a Raíces, México, UnAm, 2005 (Tesis para obtener el grado de Licenciada en Historia). 
parecieran o se convirtieran en mestizos para lograr integrarlos a la nación mexicana.

Actualmente asistimos al resurgimiento de lo que Gilberto Giménez Montiel llama "las reivindicaciones identitarias sub-nacionales" como respuesta a las pretensiones homogeneizantes del Estado centralizador y de las hegemonías capitalistas. ${ }^{20}$ Los pueblos originarios pugnan cotidianamente contra los estereotipos y representaciones coloniales que los han subyugado por siglos, por una parte, reapropiándose de una identidad que les fue formulada por el grupo dominante y, por otra, adueñándose de los medios para definir por sí mismos y según sus propios criterios su identidad. Una manera de tomar las riendas para construir y reformular su propia representación es mediante el manejo de los medios de comunicación, como es el caso de la radio, el cine y fundamentalmente el video, en los que intentan otras formas de articulación discursiva que subviertan las visiones vacías de las hegemonías culturales, construyendo nuevos órdenes discursivos. Los proyectos de etnicidad de los movimientos indígenas son luchas que no se dan en el mero ámbito político, la disputa por el reconocimiento y la autodeterminación se encuentra en las expresiones culturales de los distintos grupos indígenas y no sólo tiene que ver con los elementos meramente tradicionales, como rituales, cantos o bailes; se manifiesta también en los intentos cotidianos de participación en los medios de comunicación tecnológica y en la pugna constante por una representación propia. En ese sentido, la crítica a la cinta Apocalypto es una síntesis que nos permite ver que las producciones culturales no son simples y asépticas, sino que se encuentran en el centro de los debates actuales por el poder. La cultura se conforma de "diferentes definiciones, estilos, cosmovisiones e intereses en pugna" ${ }^{21}$ y ha sido, desde siempre, un campo de batalla donde se oponen distintas posiciones ante el mundo, formas de ver heterogéneas y, desde

${ }^{20}$ Giménez, op. cit., p. 14.

${ }^{21}$ Edward Said, "Cultura, identidad e historia", en Gerhart Schröder y Helga Breuninger [comps.], Teoría de la cultura. Un mapa de la cuestión, Argentina, FCE, 2005, p. 52. 
luego, múltiples maneras de representar. No se encuentra al margen de los procesos sociales, políticos y económicos, ya que éstos la determinan al tiempo que ella los configura. El debate por la identidad indígena se exterioriza en diversos ámbitos que superan los canales de la política tradicional y las pugnas por el poder político institucional, buscando influir y transformar las hegemonías económicas y culturales.

La presencia de los grupos indígenas en la producción de comunicación tecnológica y masiva ha sido más conflictiva desde las últimas dos décadas del siglo Xx, en algunas ocasiones se ha intentado resolver el problema apelando al orden interestatal global, mediante la promulgación de leyes o decretos. Una de las primeras experiencias fue el convenio 169 de la Organización Internacional del Trabajo, que en el apartado VI, artículo 30, referido a la educación y a los medios de comunicación, consignaba lo siguiente:

1. Los gobiernos deberán adoptar medidas acordes a las tradiciones y culturas de los medios interesados, a fin de darles a conocer sus derechos y obligaciones

2. A tal fin, deberá recurrirse, si fuese necesario a tradiciones escritas y a los medios de comunicación de masas en las lenguas de dichos pueblos. ${ }^{22}$

Aunque este convenio, formulado hacia 1989, ha resultado un instrumento jurídico muy útil para los pueblos indígenas, en cuanto al manejo de los medios de comunicación resulta marginal, pues los mantiene como una herramienta al servicio exclusivo del Estado.

Ante la hegemonía cultural de los no indígenas sobre los grupos originarios se comenzó a gestar un enfrentamiento abierto por la representación y la construcción de imágenes tecnológicas propias. Estos cuestionamientos tomaron fuerza en la escena cultural latinoamericana desde los años ochenta. En México las experiencias estéticas indígenas

${ }^{22}$ Magdalena Gómez, Derechos indígenas. Lectura comentada del Convenio 169 de la OIT, México, Instituto Nacional Indigenista, 1991, p. 88. 
en los medios audiovisuales han sido parte de un proceso que comenzó con la "transferencia de medios", donde se les dio por primera vez la posibilidad de construir su propia imagen por medios audiovisuales, contando con el apoyo más o menos sistemático de antropólogos y de documentalistas. El Instituto Nacional Indigenista coordinó algunas de las actividades de creación cinematográfica en las comunidades, al igual que ciertas organizaciones no gubernamentales, abriendo el camino de lucha por las tecnologías. Una experiencia pionera fue el ejercicio hecho por el documentalista y cineasta Luís Lupone, quien en la década de los años ochenta realizó la transferencia de medios a unas mujeres ikoods (huaves) de Oaxaca. El resultado fue Tejiendo mar y viento y La vida de una familia Ikoods (1985), donde las mujeres de la comunidad de San Mateo del Mar construyeron uno de los primeros documentos visuales indígenas mexicanos. La protagonista de esta experiencia fue Teófila Palafox, una tejedora que logró reconstruir, por medio de imágenes visuales, a su comunidad. La mirada de Teófila Palafox fue precursora e incursionó en terrenos novedosos abriendo posibilidades para nuevas formas de creación desde los ojos indígenas.

En la misma década, concretamente en 1985, se funda en la ciudad de México el Concejo Latinoamericano de Cine y Comunicación de los Pueblos Indígenas (CLACPI), organismo que desde sus orígenes ha estado comprometido con "los procesos comunicacionales asumidos por los pueblos indígenas en su lucha por el derecho a un mayor protagonismo en la elaboración, circulación de mensajes audiovisuales y acceso a la autogestión comunicacional." ${ }^{23}$ A la par de su fundación se realizó el Primer Festival de Cine y Video de los pueblos indígenas y desde entonces se han desarrollado festivales en Brasil (1987), Venezuela (1989), Perú (1992), Bolivia (1996), Guatemala (1999), Chile (2004) y el último en la ciudad de Oaxaca, México (2006). En el quinto festival, llevado a

${ }^{23}$ El Consejo Latinoamericano de Cine y Comunicación de los Pueblos Indígenas: a manera de presentación. En http://videoindigena.bolnet.bo/clacpi.htm. 
cabo en 1996, se efectuó una interpelación directa a las hegemonías culturales y a los detentadores de los medios masivos de comunicación. En Cochabamba, Bolivia, se firmó una carta en los siguientes términos:

Cochabamba, Bolivia, 29 de junio de 1996.

Carta Abierta:

A través del tiempo, nosotros los Pueblos Indígenas hemos sufrido el robo de nuestro "espiritu personal y comunal" mediante el uso de fotografias y cámaras audiovisuales (cine-video) que transportan nuestra imagen a otro espacio.

Nuestras vidas, nuestra historia, nuestros personajes, nuestro paisaje, nuestros ríos, nuestras montañas, que son además parte de nuestro legado, han servido de fuente para que algunos consiguieran riquezas y prestigio.

Los Pueblos Indígenas exigen de los diferentes países del mundo, representados por sus gobiernos, instituciones y organizaciones, la DEVOLUCióN de nuestra imagen, la devolución de la representación de nuestro espiritu reflejado en películas y videos.

Consideramos que los cineastas y productores escucharán esta queja de los que abrieron la puerta una vez, y que con el respeto y la dignidad característicos de los seres humanos, harán caso a la voz de los antepasados.

Especialmente los creadores de cine y de video que no sean indígenas y estén comprometidos con la causa indígena, serán los primeros en hacer frente a esta demanda.

Para preservar nuestras culturas

Para mantener nuestro espíritu en su esencia ¡EXIGIMOS LA DEVOLUCIÓN DE NUESTRA IMAGEN!

Participantes en el Foro Indígena del V Festival de Cine y Video de Pueblos Indígenas. ${ }^{24}$

A la luz de nuestro análisis las exigencias de la Carta Abierta de Cochabamba son de suma importancia porque representan una de las primeras interpelaciones de los indígenas latinoamericanos hacia las hegemonías culturales por la usurpación y explotación de su imagen tec-

${ }^{24}$ Carol Kalafatic, “CEFREC/Video en Bolivia”, Redes indigenas.

En http://www.nativenetworks.si.edu/esp/rose/cefrec.htm. Las cursivas son mías. 
nológica. ¿Qué nos permiten ver estas demandas de devolución de la imagen y del espíritu reflejado en películas y videos?

Las construcciones visuales bolivianas en torno a los indígenas han sido revolucionarias y han resultado en vanguardias cinematográficas latinoamericanas desde la segunda mitad del siglo xx. Jorge Sanjinés, el más importante cineasta boliviano, comenzó un discurso crítico contra la explotación y el imperialismo en sus primeros trabajos como Revolución (1963), Ukamau (Así es, 1966) y Yawar Malku (La sangre del Cóndor, de 1969), en las cuales la representación de los indígenas fue fundamental. Sin embargo, el propio realizador ha mantenido una posición de auto-crítica al analizar las relaciones establecidas del grupo Uka$\mathrm{mau}^{25}$ con las comunidades indígenas:

Los que teníamos un gran respeto por la cultura andina y conocíamos su potencial revolucionario - protagonista de grandes cambios históricos- teníamos un enorme interés en llegar con el cine, comunicarnos, movilizarlos. Pero nuestro desencuentro provenía ya no de la aculturación, de la alienación de esas grandes masas, sino de nuestra propia ignorancia, de nuestra propia aculturización. Ignorábamos los complejos códigos comunicacionales andinos. Estábamos formados en la cultura occidental europea y no entendíamos ni la cosmovisión de esas masas ni entendíamos sus ritmos internos. Éramos intelectuales citadinos bien intencionados, nada más. Y fue difícil entenderlo al comienzo, fue muy duro sentirnos extranjeros en nuestra propia tierra. Después de gravísimos fracasos frente a ese público que percibía nuestro cine como una nueva intromisión cultural colonizadora, tuvimos que reaccionar en proporción a nuestro fracaso $\mathrm{y}$, con humildad, reconocer los valores y complejidades de una cultura extraordinaria con la que convivíamos sin conocerla ni comprenderla. ${ }^{26}$

${ }^{25}$ Nombre que toma el equipo de realización encabezado por Jorge Sanjinés e integrado en su primera etapa por Oscar Soria, Antonio Eguino, Ricardo Rada.

${ }^{26}$ Jorge Sanjinés, "Neorrealismo y Nuevo Cine Latinoamericano: la herencia, las coincidencias y las diferencias", en El ojo que piensa. Revista virtual del Nuevo Cine Latinoamericano, núm. 0, Guadalajara, Jalisco, agosto, 2003.

En http://www.elojoquepiensa.udg.mx/espanol/numero00/veryana/07_neorrealismo.ht$\mathrm{ml}$. 
Después de varias experiencias el grupo logró sentar precedentes en la construcción de la auto-representación visual de los grupos subalternos, a través de cintas como El coraje del pueblo (1971) o El enemigo principal (1973), donde los protagonistas de sus propias historias son los grupos mineros o indígenas, quienes intervienen directamente en los guiones y en las actuaciones, logrando un trabajo conjunto de construcciones visuales. ${ }^{27}$ Después de estás producciones Jorge Sanjinés forjó una de las obras más importantes del cine latinoamericano, La nación clandestina (1989), en donde evidencia que los grupos indígenas siempre fueron parte clandestina de la nación boliviana, en el desarrollo visual de la cinta intenta sintetizar la cosmovisión indígena por medio de imágenes, específicamente, a través del "plano secuencia circular". Este filme es de suma importancia para Bolivia y para el resto del continente porque representa uno de los intentos más serio y exitoso de construcción visual de los grupos indígenas. El actual movimiento de videoastas indígenas en Bolivia tiene una cierta relación de sucesión con las experiencias pioneras del Grupo Ukamau.

Desde 1989 el movimiento indígena en Bolivia inició experiencias de trabajo con la reproducción técnica de las imágenes. En ese año se fundó el Centro de Formación y Realización Cinematográfica (CEFREC) como resultado de una lucha contra los medios de comunicación hegemónicos y sus estereotipos, que denigraron por mucho tiempo la cultura indígena, entre sus objetivos estaban: "encontrar formas de utilizar los medios como una herramienta de gran fuerza para la autodeterminación". ${ }^{28}$

El proceso boliviano frente a los medios de comunicación visual ha sido una revolución en el campo de la lucha indígena, pues las demandas económicas y políticas se complementaron con las de reproducción simbólica de la vida como elemento central; no sólo se pugnó por la resti-

${ }^{27}$ Para más información de estos revolucionarios procesos cinematográficos véase Jorge Sanjinés, Teoría y práctica de un cine junto al pueblo, $3^{\circ}$ ed., México, Siglo XXI, 1987.

${ }^{28}$ Carol Kalafatic, "CEFREC/Video en Bolivia", Redes indígenas.

En http://www.nativenetworks.si.edu/esp/rose/cefrec.htm. 
tución de la riqueza material de los pueblos indios, sino que también se luchó por la expropiación de los contenidos simbólicos encriptados en burdos y estereotipados productos audiovisuales. En esos años se consolidó un mecanismo muy importante: la utilización de los medios masivos como articuladores de tradición y modernidad, para ingresar a los caminos de la comunicación y fortalecer la lucha política y la autodeterminación.

Este proceso se apuntalaría en el año de 1996 cuando se impulsó la primera experiencia de largo aliento de transferencia de medios a través del Plan Nacional Indígena Originario de Comunicación Audiovisual, que se sigue llevando a cabo hasta la fecha y que desde sus orígenes tuvo el apoyo de importantes organizaciones de la escena política boliviana, como la Confederación Sindical Única de Trabajadores Campesinos, la Confederación de los Pueblos Indígenas de Bolivia y la Confederación Sindical de Trabajadores de Bolivia, estas organizaciones junto con la Coordinadora Audiovisual Indígena de Bolivia (CAIB) y el Centro de Formación y Realización Cinematográfica (CEFREC) impulsaron la querella por la auto-representación de los grupos originarios. Las experiencias se combinaron con la práctica de radiodifusión que había sido de suma importancia en las movilizaciones mineras previas como un medio de fomentar los valores culturales. Es muy importante que este plan tuviera entre sus objetivos "dar fuerza a la auto-representación indígena, tomando posesión de la tecnología para que los propios pueblos creen su imagen". ${ }^{29}$ Los planteamientos surgidos del Plan Nacional se consolidaron en experiencias significativas de descolonización de las representaciones de los indígenas. Y, a la fecha, han fincado un fructífero campo de producción que se distribuye en muchos circuitos tanto nacionales como internacionales. Sin embargo, el éxito no sólo se ha dado en la gran cantidad de producciones y en los premios obtenidos: sobre 
todo se ha logrado en el ámbito de la política y de la lucha por las hegemonías, pues el hecho de que el primer presidente indígena, Evo Morales, llegara al poder tiene que ver, entre otros muchos fenómenos, con un cambio en las representaciones y auto-representaciones sociales de los indígenas en un país como Bolivia, donde la lucha por las imágenes ha sido y sigue siendo fundamental.

Las desigualdades en la producción y distribución de estas producciones aún continúan, mientras el modo de producción visual hollywoodense sigue penetrando en muchos de los ámbitos culturales latinoamericanos e imponiendo sus pautas, los productos audiovisuales indígenas llegan de manera esporádica a los canales latinoamericanos y del primer mundo. Los grupos indígenas se enfrentan a muchos problemas que tienen que ver, tanto con el acceso a las nuevas tecnologías, como a la distribución y el financiamiento de sus materiales. Asimismo existen conflictos importantes con los formatos y los tiempos de sus producciones, ya que difieren mucho de los tradicionales para televisión o de los impuestos por las cinematografías comerciales.

Las sociedades latinoamericanas seguimos visualizando el mundo con el mediador epistemológico que ha significado la industria cultural estadounidense y las hegemonías visuales locales, mientras las miradas indígenas se encuentran una vez más al margen y enfrentando muchas dificultades de aceptación, popularización y acceso a espacios de difusión más amplios.

A pesar de los problemas económicos y tecnológicos, el cine y el video indígena están construyendo alternativas y nuevas formas de lucha en América Latina. Las producciones visuales nativas implican relaciones inéditas con la memoria y la historia mediante la utilización de la tecnología, posibilitando la subversión de las categorías visuales tradicionales en las que los nacionalismos y las hegemonías culturales inscribieron a los grupos originarios. En el último Festival de cine y video de los pueblos indígenas se exhibió una película que podría ilustrar muy bien este fenómeno titulada Meu Primeiro Contato (Mi Primer Contacto, 
2005) en la que el pueblo Ikpeng del Brasil reconstruye, por medio de imágenes, el primer contacto que sostuvieron con los "hombres blancos" hace casi cuarenta años. Mediante el registro de las narraciones del encuentro, hombres y mujeres que ahora son viejos nos relatan ese periodo de su niñez y permiten penetrar en ese otro lado de la historia que ha sido negada u olvidada.

Las producciones indígenas rescatan la lengua y las prácticas tradicionales posibilitando, al mismo tiempo, la transmisión de saberes mediante la utilización de las potencialidades de la oralidad y la visualidad, elementos que son fundamentales en las cosmovisiones indígenas. En la producción boliviana Desempolvando nuestra historia (1999) las comunidades de Caltapi y Silvi, en el departamento sureño de Potosí, generan una compleja representación visual de su vida por medio del video, donde formulan una reconstrucción histórica novedosa enumerando las cosas que persisten y las que han desaparecido de su cultura y su entorno, recorriendo toda la organización social, las prácticas culturales, hasta llegar a la fauna que se ha extinguido. Éste es un ejercicio importante de reconstrucción histórica mediante las imágenes donde no entran en juego los elementos de la grafia, es decir de la escritura de la historia que tradicionalmente ha marginado a los indígenas.

¿Cómo se va a devolver la imagen, la representación usurpada, a los pueblos indígenas? Pues generando posibilidades reales de creación estética (económica y tecnológica) para la política indígena y principalmente para la reproducción de sus identidades. Cuando los indígenas construyen su representación existe la posibilidad de transgredir la dominación, la marginalidad y la exclusión por medio de las imágenes. En los videos, ya sean tramas documentales, de ficción o video clips, se auto-construyen como sujetos móviles, participativos y con voluntad de decisión. La mayoría de los videoastas están representando de un modo diferente sus visiones de mundo y el arraigo a la tierra, no están enfrascados en los esencialismos culturales del nacionalismo chovinista. Por el contrario, exaltan la movilidad de la cultura y de las propias personas, no están esperando la fatalidad, prefieren el dinamismo que resulta 
vital. ${ }^{30}$ Por medio de las imágenes nos invitan a nuevas formas de construir la otredad, nuevas formas de practicar la política y de enfocar el mundo. En ese sentido en El venado yaqui (2003), documental exhibido en el festival de Oaxaca del año pasado, Esperanza Molina registra la forma en que se baila la danza del venado dentro de la tribu yaqui de Sonora; en escasos quince minutos apreciamos la materialización de la cosmovisión de los indígenas yaquis en imágenes en mutación. Este documental es una recuperación de las tradiciones que se aleja de lo folclórico, es una mirada fresca de la fiesta y de los rituales que rompe con muchas de las imágenes colonizadoras y homogeneizantes que ha construido por años el cine mexicano, donde las fiestas nunca se representaron con densidad geográfica ni étnica. Utilizando las mismas armas culturales, como es la producción en video, los indígenas están generando contradiscursos que salen de los márgenes, del foco cultural, que el nacionalismo ha impuesto.

Las miradas indígenas son un ejercicio descolonizador, ya que están cambiando el lugar de la enunciación, que no sólo se ha transportado a los ojos indios, sino que comienzan a nombrar y a representar la realidad desde la pluralidad, impulsando un ejemplo de la lucha contra las visiones hegemónicas. ${ }^{31}$ Impugnan los cánones clásicos del nacionalismo mediante la ruptura de la visión monolítica de "lo indígena" y se manifiestan contra una localización estática, conformando un nuevo modo de mirar, una forma de transitar a la interculturalidad sin caer en la homogeneización. Al mismo tiempo que proponen alternativas a la visión dominante del mundo, por ejemplo a través de un contacto diferente con la natura-

${ }^{30}$ Por ejemplo las investigaciones de la chatina Yolanda Cruz sobre la migración oaxaqueña a Estados Unidos en el documental Sueños binacionales (2005), que nos muestra la solidaridad y las formas de soñar a ambos lados de la frontera.

${ }^{31}$ Cuando revisaba este artículo para su publicación descubrí el libro de Freya Schiwi y Nelson Maldonado Torres, (Des) Colonialidad del ser y del saber (videos indígenas y los límites de la izquierda) en Bolivia, Buenos Aires, Del Signo, 2006. Con el cual comparto muchas ideas, principalmente la posibilidad descolonizadora de los videos indígenas. 
leza, tal es el caso del video Mana Khawakuaychu (Hagamos algo contra la basura, 2000) que genera una crítica y propuestas concretas para resolver el problema de la basura en las comunidades indígenas de Bolivia. $^{32}$

La guerra continúa a pesar de que en la Declaración Universal de los Derechos Humanos de los Pueblos Indígenas (junio, 2006), se les asigna la potestad de establecer sus propios medios de comunicación y difusión, "la posibilidad de contar con todos los recursos de la tecnología sin ninguna discriminación, además de tener acceso a todas las formas de comunicación y difusión no indígena" (Art. 16). En la Declaración del Encuentro Internacional de Comunicación y Desarrollo de los Pueblos Indígenas realizado del 13 al 15 de septiembre de 2006 en Santa Cruz, Bolivia, persistieron las peticiones de equidad y libre acceso a los canales hegemónicos manifestando lo siguiente: "Requerimos que se amplíe de manera significativa la presencia de los medios comunitarios y la presencia de los Pueblos Indígenas en los medios masivos." 33

La apropiación de los espacios de producción y difusión de materiales audiovisuales por parte de los grupos indígenas ensancha el camino de la lucha por subvertir las relaciones de poder colonial en las que viven. El movimiento indígena no sólo existe en los espacios de la política institucional, sino que ha ido deslizándose por los distintos niveles estructurales de la organización social capitalista, para hacerse oír en cada uno de ellos. Este proceso ha reformulado el problema de la voz de los subalternos, dejando claro que son sujetos con pleno derecho de hablar, mirar y enunciar el mundo desde su orden simbólico y mediante la construcción de nuevas tramas narrativas. Retomando las reflexiones de la intelectual boliviana Silvia Rivera Cusicanqui, el conflicto ya no

${ }^{32}$ Quiero agradecer al CEFREC de Bolivia que me permitió el acceso a éste y otros materiales visuales indígenas, que por cuestiones de tiempo no pude incluir en este análisis.

${ }^{3}$ DECLARACIÓN DEL ENCUENTRO INTERNACIONAL DE COMUNICACIÓN Y DESARROLLO DE LOS PUEBLOS INDÍGENAS, Santa Cruz (Bolivia), 13 al 15 de septiembre, 2006.

En http://www.un.org/esa/socdev/unpfii/documents/comunicacion_desarrollo.doc. 
es si ¿pueden hablar (o construir visualidades) los subalternos? Pues en un continente de sorderas y cegueras coloniales "valdría la pena invertir la pregunta: ¿pueden escuchar [y ver] las élites dominantes lo que dice el subalterno cuando habla? Quizá aquí reside el por qué de la lucha simbólica, y de la propia violencia como lenguaje". ${ }^{34}$ La apropiación de medios tecnológicos de comunicación abre a los grupos indígenas las posibilidades de ser vistos y oídos por los consumidores de narrativas occidentalizadas que los han ignorado por siglos. La guerra no ha terminado, junto a la lucha contra las exclusiones económicas y sociales se tiene que continuar la batalla contra los cánones visuales que reproducen la dominación, como los formulados en filmes como Apocalypto.

\section{BIBLIOGRAFÍA}

Althusser, Louis, "Ideología y aparatos ideológicos de estado", en $L a$ filosofía como arma de la revolución, 8ª ed., México, Siglo XXI, 1977 (Cuadernos de pasado presente, 4).

Anderson, Benedict, Comunidades imaginadas. Reflexiones sobre el origen y difusión del nacionalismo, México, FCE, 2005.

BARTRA, ARMANDO, "Imágenes encontradas", La Jornada, Sección Hojarasca, año 9, núm. 23, marzo, 1999.

Castells Italens, Antoni, "Cine indígena y resistencia cultural", $R e$ vista Latinoamericana de Comunicación Chasqui, núm. 084, Quito, Centro Internacional de Estudios Superiores de Comunicación para América Latina, diciembre, 2003, pp. 50-57.

Cinemateca Boliviana, Cronología del cine boliviano (1897-1997), Notas críticas 61, La Paz, Bolivia, Ediciones de la cinemateca boliviana, noviembre, 1997.

${ }^{34}$ Silvia Rivera Cusicanqui, "Mirando al pasado para caminar por el presente y el futuro (qhip nayr uñtasis sarnaqapxañani)", prefacio de la autora a Oprimidos pero no vencidos: luchas del campesinado aymara y qhechwa, 1900-1980, 4ª ed., La Paz, Bolivia, Aruwiriyiri, Editorial del Taller de Historia Oral Andino, 2003, p. 56. 
DÁvalos Orozco, Federico, Albores del cine mexicano, México, Editorial Clío, 1996.

Davalos, Pablo [comp.], Pueblos indígenas, Estado y democracia, Buenos Aires, CLACSO, 2005.

En http://bibliotecavirtual.clacso.org.ar/ar/libros/davalos/davalos.html.

DECLARACIÓN DEL ENCUENTRO INTERNACIONAL DE COMUNICACIÓN Y DESARROLlo de los PUEBlos IndígenAs, Santa Cruz, Bolivia, 13 al 15 de septiembre de 2006. En http://www.un.org/esa/socdev/unpfii/documents/comunicacion_desarrollo.doc

FeIN, SETh, "La diplomacia del celuloide. Hollywood y la edad de oro del cine mexicano", en Historia y Grafia, Revista Semestral, núm. 4, año 2, Universidad Iberoamericana, 1995.

Festival InTERnacional De CINE Y VIDEO De Oruro, Plano detalle del cine boliviano, La Paz, Bolivia, Plural Editores, 2005.

GiMÉNEZ, GILBERTO, “Identidades étnicas: estado de la cuestión”, en Leticia Reina [coord.], Los retos de la etnicidad en los estados-nación del siglo XXI, México, CIESAS/INI/Porrúa, 2000, pp. 45-70.

Gómez, Magdalena, Lectura comentada del convenio 169 de la Organización internacional del trabajo, México, INI, 1991.

Gumucio Dagrón, Alfonso, Historia del cine boliviano, México, Filmoteca de la UNAM, 1983. , Historia del cine en Bolivia, Oruro, Bolivia, Editorial Los amigos del libro, 1982.

Kalafatic, CAROL, “CeFrec/Video en Bolivia”, Redes indígenas. En http://www.nativenetworks.si.edu/esp/rose/cefrec.htm.

LEÓn, CRISTIAN, "Racismo, políticas de la identidad y construcción de 'otredades' en el cine ecuatoriano", Revista Chilena de antropología visual, Universidad Academia de Humanismo Cristiano. En http://www.antropologiavisual.cl/leon_imprimir.htm.

LeZAma, Luís, Argumento de Tabaré, edición facsimilar, introd. y estudio preliminar de Federico Dávalos Orozco, Cineteca Nacional.

Mahieu, José Agustín, Panorama del cine Iberoamericano, Madrid, Ediciones Cultura Hispánica, 1990. 
Mesa Gisbert, Carlos de, La aventura del cine boliviano (1952-1985), La Paz, Bolivia, Editorial Gisbert, 1985.

Peredo Castro, Francisco, Cine y propaganda para Latinoamérica. México y Estados Unidos en la encrucijada de los años cuarenta, México, CCYDEL-CISAN-UNAM, 2004.

QuiJano, AníBAL, “'Raza', 'etnia’ y 'nación' en Mariátegui. Cuestiones abiertas", en José Carlos Mariátegui y Europa: La otra cara del descubrimiento, Lima, Amauta, 1992.

Reyes, Aurelio de los, Manuel Gamio y el cine, México, unAM-Coordinación de Humanidades, 1991.

, Medio siglo de cine mexicano (1896-1947), México, Trillas, 1987 (Linterna Mágica, 10).

Río, JoEL DEL, "Precursores, nacimiento y plenitud del Nuevo Cine Latinoamericano", Miradas, núm. 8, 2005.

En http://www.miradas.eictv.co.cu/content.php?id_articulo=296 Rivera Cusicanqui, Silvia, Oprimidos pero no vencidos: luchas del campesinado aymara y qhechwa, 1900-1980, $4^{\mathrm{a}}$ ed., La Paz, Bolivia, Aruwiriyiri, Editorial del Taller de Historia Oral Andino, 2003. SAID, EDWARD, Cultura e imperialismo, Barcelona, Anagrama, 1996. , Orientalismo, $3^{\mathrm{a}}$ ed., Barcelona, Ediciones De bolsillo, 2004.

SAnJinés, Jorge y Grupo UkAmau, Teoría y práctica de un cine junto al pueblo, $3^{\mathrm{a}}$ ed., México, Siglo XXI, 1987.

, "El perfil imborrable", en El Nuevo Cine Latinoamericano en el mundo de hoy. Memoria del IX Festival Internacional del Nuevo Cine Latinoamericano, México, UNAM, 1988.

,"Neorrealismo y Nuevo Cine Latinoamericano: la herencia, las coincidencias y las diferencias", El ojo que piensa. Revista virtual del Nuevo Cine Latinoamericano, núm. 0, Guadalajara, Jalisco, México, agosto, 2003.

Schröder, Gerhart y Helga Breuninger [comp.], Teoría de la cultura. Un mapa de la cuestión, Argentina, FCE, 2005. 
Ukhamawa, sábado 9 de diciembre, 2006.

En http:/espanol.groups.yahoo.com/group/ukhamawa/

FILMOGRAFÍA

- Apocalypto

Año: 2006, dirección: Mel Gibson, país: USA, producción: Mel Gibson y Bruce Davey, argumento: Mel Gibson y Farhad Safinia.

- Corazón aymara

Año: 1925, dirección: Pedro Sambarino, país: Bolivia, producción: Bolivia Films, argumento: Pedro Sambarino.

- La profecía del lago

Año: 1925, dirección: José María Velasco Maidana, país: Bolivia, producción: Urania Films, argumento: José María Velasco Maidana.

- La gloria de la raza

Año: 1926, dirección: Arturo Posnansky, país: Bolivia, producción:

Cóndor Mayku Films, argumento: Arturo Posnansky.

- Wara-wara

Año: 1939, dirección: José María Velasco Maidana, país: Bolivia, producción: Urania Films, argumento: José María Velasco Maidana.

- Janitzio

Año: 1934, dirección: Carlos Navarro, país: México, producción: Cinematográfica Mexicana S.A, argumento: Luís Márquez.

- La noche de los mayas

Año: 1938, dirección: Carlos Navarro, país: México, producción: Cinematográfica Mexicana S.A, argumento: Antonio Mediz Bolio, adaptación: Chano Urueta.

- María Candelaria

Año: 1943, dirección: Emilio Fernández, país: México, producción: Films Mundiales, Agustín J. Fink, argumento: Emilio Fernández y Mauricio Magdaleno. 


\section{- Río Escondido}

Año: 1947, dirección: Emilio Indio Fernández, país: México, producción: Raúl de Anda, argumento: Emilio Fernández y Mauricio Magdaleno.

- Tizoc

Año: 1956, dirección: Ismael Rodríguez, país: México, argumento: I.

Rodríguez, Carlos Orellana, Manuel R. Ojeda y Ricardo Parada León.

- Lola Casanova

Año: 1948, dirección: Matilde Landeta, país: México, producción: TACMA, argumento: de la novela homónima de Francisco Rojas González, adaptación: Matilde Landeta.

- Tejiendo mar y viento

Año: 1985, dirección: Luís Lupone, país: México, producción: Heléne Damet, Juan Francisco Urrusti, argumento: Luís Lupone.

- La vida de una familia Ikoods

Año: 1985, dirección: Teófila Palafox, país: México, producción: Juana Canseco, argumento: Colectivo.

- Revolución

Año: 1964, dirección: Jorge Sanjinés, país: Bolivia, producción: Independiente, argumento: Jorge Sanjinés y Oscar Soria.

- Ukamau/Así es

Año: 1966, dirección: Jorge Sanjinés, país: México, producción: Instituto Cinematográfico Boliviano, argumento: Jorge Sanjinés y Oscar Soria.

- Yawar Mallku/La sangre del cóndor

Año: 1969, dirección: Jorge Sanjinés, país: Bolivia, producción:

Grupo Ukamau, argumento: Oscar Soria y Jorge Sanjinés

- El coraje del pueblo

Año: 1971, dirección: Jorge Sanjinés, país: Bolivia, producción: Grupo Ukamau y Radio Televisión Italiana, argumento: Oscar Soria y Jorge Sanjinés. 
- Jatun Auka/El enemigo principal

Año: 1974, dirección: Jorge Sanjinés, país: Ecuador, producción:

Grupo Ukamau en el exilio, argumento: Jorge Sanjinés, Oscar Sambrano, con base en documentos y relatos de una historia real.

- La nación clandestina

Año: 1989, dirección: Jorge Sanjinés, país: Bolivia, producción:

Grupo Ukamau, argumento: Jorge Sanjinés.

- Meu Primeiro Contato /Mi primer contacto

Año: 2005, dirección: Mari Corrêa y Kumaré Txicão (Ikpeng), país:

Brasil, comunidad: Ikpeng, producción: Video nas Aldeias.

- Desempolvando nuestra historia

Año: 1999, responsable: Alfredo Copa, país: Bolivia, comunidades:

Caltapi y Silvi, producción: CEFREC-CAIB, argumento: Alfredo Copa.

- Sueños binacionales

Año: 2005, dirección: Yolanda Cruz, país: México, producción: Petate Producciones.

- El venado yaqui

Año: 2003, dirección: Maria Esperanza Molina Rojas, país: México, comunidad: Sarmiento yaqui Sonora, Producción: Organización Productora: UPAI-Sonora CDI, argumento: Maria Esperanza Molina Rojas.

- Mana Khawakuaychu/Hagamos algo contra la basura plástica

Año: 2000, responsable: Jacinta Rodríguez, país: Bolivia, producción: CEFREC-CAIB, argumento: Jacinta Rodríguez. 